\title{
Development and Validation of a Standardized Questionnaire and Standardized Diary for Use in Integrative Medicine Consultations in Gynecologic Oncology
}

\author{
Entwicklung und Validierung eines standardisierten Fragebogens und eines standardisierten Tagebuchs \\ für die Sprechstunde für Integrative Medizin in der Gynäkologischen Onkologie
}

Authors

Affiliation
C. C. Hack, N. B. M. Hüttner, P. A. Fasching, M. W. Beckmann

Department of Gynecology and Obstetrics, University Hospital Erlangen, Erlangen

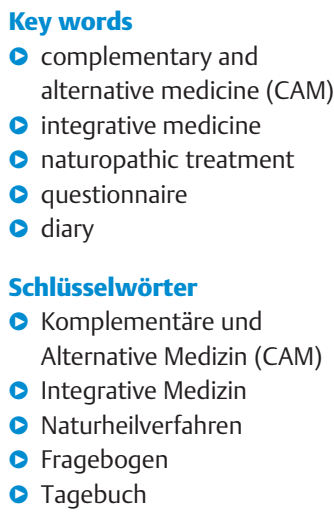

\section{received 14.2.2015 \\ revised 7.3 .2015 \\ accepted 7.3.2015}

\section{Bibliography}

DOI http://dx.doi.org/

10.1055/s-0035-1545850

Geburtsh Frauenheilk 2015; 75 :

377-383 @ Georg Thieme

Verlag KG Stuttgart · New York . ISSN 0016-5751

\section{Correspondence}

\section{Dr. Carolin C. Hack}

University Hospital Erlangen

Department of Gynecology and Obstetrics

Universitätsstraße 21-23

91054 Erlangen

carolin.hack@uk-erlangen.de

\section{Abstract \\ $\nabla$}

Introduction: Use of complementary and alternative medicine (CAM) in diagnoses is not standardized and is very heterogeneous. There are few published standards on integrative medicine consultations or CAM-specific validated follow-up questionnaires. The aim of this study was to develop a standard for integrative medicine consultations, a patient questionnaire which could be used as a basis for medical decisions, and a diary to evaluate the course of the integrative therapy. Patients and Methods: Between June 2013 and September 2014 a standardized integrative medicine consultation in gynecologic oncology was developed and implemented at the Department of Gynecology and Obstetrics of Erlangen University Hospital. A standard operating procedure for consultations was developed; the necessary instruments were developed and validated.

Results: Overall patient assessment of the integrative medicine questionnaire and the integrative medicine diary with regard to the time required for completion, comprehensibility, complexity and functionality was positive. Patients evaluated the standardized overall concept of the integrative medicine consultation and its instruments as suitable.

Conclusion: Our team is one of the first study groups to develop, validate and publish a standard procedure for integrative medicine consultations. In future, the standard operating procedure for integrative medicine procedures of the Department of Gynecology and Obstetrics of Erlangen University Hospital could be introduced in other hospitals and certified breast cancer centers and gynecologic cancer centers. This would offer patients maximum security and a standardized quality of care in integrative medicine.

\section{Zusammenfassung \\ $\nabla$}

Einleitung: Der Einsatz von Komplementärer und Alternativer Medizin ist in der Indikation nicht standardisiert und sehr heterogen. Es gibt wenige publizierte Standards zur Durchführung einer Sprechstunde für Integrative Medizin und zum Einsatz von CAM-spezifischen validierten Follow-up-Fragebögen. Ziel war es, einen Standard für eine Sprechstunde für Integrative Medizin, einen Patientinnenfragebogen als Basis für die Therapieentscheidung und ein Tagebuch zur Verlaufsbeurteilung des Einsatzes der Integrativen Therapiemethoden zu etablieren.

Patienten und Methoden: Von Juni 2013 bis September 2014 wurde an der Frauenklinik der Universitätsklinikums Erlangen eine standardisierte Sprechstunde für Integrative Medizin im Rahmen der Gynäkologischen Onkologie aufgebaut und etabliert. Es wurde eine „standard operation procedure" für den Ablauf der Sprechstunde entwickelt, das hierfür notwendige Instrumentarium erstellt und validiert.

Ergebnisse: Die Patientinnen beurteilten den Fragebogen für Integrative Medizin und das Tagebuch für Integrative Medizin bez. Zeitaufwand, Verständlichkeit, Komplexität und Funktionalität als positiv. Das standardisierte Gesamtkonzept der Sprechstunde für Integrative Medizin und das hierfür notwendige Instrumentarium wurden von den Patientinnen als geeignet beurteilt.

Schlussfolgerung: Unser Team hat als eine der ersten Arbeitsgruppen überhaupt einen Standard für die Durchführung einer Sprechstunde für Integrative Medizin entwickelt, validiert und publiziert. Zukünftig könnte der Ablauf der Sprechstunde für Integrative Medizin aus der Frauenklinik des Universitätsklinikums Erlangen auch in anderen Kliniken und zertifizierten Brust- bzw. Gynäkologischen Krebszentren als „standard operation procedure" eingeführt werden. Der Patientin kann somit die größtmögliche Sicherheit und 
eine standardisierte Qualität auch in der Integrativen Medizin geboten werden.

\section{Introduction}

Use of complementary therapies as part of the concept of integrative medicine has significantly increased in recent years [ 1 , 2]. Integrative medicine is a collective term used to describe a combination of scientific, evidence-based medicine (conventional mainstream medicine) and complementary, experience-based medicine (expertise; “complementary medicine"). This approach integrates complementary methods which aim to contribute to the holistic care of patients with currently practiced medical treatment. Such complementary methods are considered to offer additional and supplementary assistance within the current medical system; they are not considered replacements for conventional medicine. "Complementary medicine" and "complementary and alternative medicine" (CAM) are often used interchangeably. According to the definition, CAM includes all complementary and alternative methods of treatment, ranging from controversial and untested products and therapies to effective supportive measures [3].

Integrative medicine is particularly popular in oncology [4-6]. Around $40 \%$ of cancer patients in Germany use CAM during or after cancer treatment [7]. Since the 1970s, the percentages of cancer patients in western industrialized nations using CAM has continually risen, from 25 to $49 \%$ [7-10]. In the USA, Australia and Europe between 38 and $60 \%$ of all cancer patients use CAM during the course of disease for therapeutic support $[1,11,12]$. The percentage is even higher among breast cancer patients where, depending on the cancer stage, it can be as high as $90 \%$ $[2,13,14]$. Patients with advanced or metastatic cancer use CAM more frequently than patients with early-stage disease $[15,16]$. A German study which aimed to identify predictive factors for the use of CAM in patients with various cancer entities (including breast cancer, gynecologic genital cancer) undergoing radiotherapy found that $39 \%$ of cancer patients with stage I disease and $54 \%$ with stage II disease used CAM over the course of disease. In stages III and IV the figure was 70\% of all cancer patients [17]. Studies confirm that integrative medicine can help to reduce the side-effects of modern cancer therapies or of the cancer itself [18-20] and can improve patients' quality of life [21-23]. Common methods in integrative medicine include homeopathy, anthroposophic medicine, in particular mistletoe therapy, classic naturopathic treatment, phytotherapy, traditional Chinese medicine (TCM) including acupuncture, sports, nutritional approaches, vitamin products, mineral nutrients, dietary supplements and relaxation therapies [21,22,24-27].

The use of integrative medicine is not standardized and is very heterogeneous. The reason for this is that globally there are no general guidelines or standards for CAM. There are only websites, databases and medical literature which address individual aspects of integrative medicine and offer CAM-related information of varying quality [28-30].

There are almost no published standards outlining how to carry out an integrative medicine consultation or on the use of validated CAM questionnaires to provide basic information for the consultation or on general therapeutic recommendations on CAM; in particular, there are no standards for interdisciplinary integrative medicine conferences in which therapeutic decisions are taken [7,31-33]. Treatment plans are decided on interdisciplinary con- ferences and these conferences form the basis for the quality of care offered to oncology patients in certified cancer centers [3442]. There are no validated CAM questionnaires in the literature which could be used as a basis for CAM therapy decisions taken in a patient consultation in gynecologic oncology. Drug safety, drug interactions, contraindications, the wishes and goals of the patient are often not adequately taken into account. A detailed patient history using a general questionnaire to determine the patient's medical history and a CAM-specific questionnaire to obtain such information are therefore indispensable.

The aim was to develop and validate a standardized patient questionnaire which would serve as the basis for therapeutic decisions on integrative medicine in gynecologic oncology, a standardized diary to assess the course of treatment using integrative therapy, and a standardized procedure for integrative medicine consultations together with the required instruments.

\section{Patients and Methods}

$\nabla$

Between June 2013 and September 2014 a standardized procedure for integrative medicine consultations in gynecologic oncology, i.e. for use by certified breast centers and gynecologic cancer centers, was developed at the Department of Gynecology and Obstetrics of Erlangen University Hospital. A "standard operating procedure" (SOP) was developed for the consultation and the required instruments were created and validated.

\section{SOP for integrative medicine consultations}

The procedure for the integrative medicine consultation is organized into four consecutive stages ( $\bullet$ Fig. 1). The first stage consists of initial presentation by the patient in person along with detailed collection of data about the patient's general, oncologic and - if present - CAM-specific medical history, followed by a compilation of all findings relevant for diagnosis and for the decision regarding treatment. A patient questionnaire (IMed questionnaire) was developed and validated to obtain basic information in a standardized form.

After the data and documents have been collected and ordered, the patient presents a second time, this time to an interdisciplinary integrative medicine conference, and an individual therapy plan is developed for the patient.

The goal is to offer patients maximum safety and efficacy for both therapeutic approaches - oncologic therapy and integrative medicine - by checking drug interactions and the safety of prescribed medicines, thereby avoiding side-effects, toxicities or reductions in the efficacy of the therapies. For quality assurance purposes, the patient is required to present to medical practitioners at two separate appointments. An individual all-round treatment plan is developed based on disease, standard therapy required, pre-existing complaints and the results of the investigation into the safety of prescribed medicines in a specific database, which is tailored to the patient's needs and wishes.

The patient is requested to present herself a second time and the interdisciplinary patient plan is explained to her. To assess the course of the integrative therapies, patients are given a standardized and validated diary (IMed diary) for a period of one year. The patient must present again for follow-up 3-6 months later. 
Standard Operating Procedure (SOP) for Integrative Medicine Consultations

\begin{tabular}{|c|c|}
\hline \multirow[t]{2}{*}{$\begin{array}{l}\text { Integrative medicine } \\
\text { consultation }\end{array}$} & $\begin{array}{l}\text { Initial appointment attended by the patient } \\
\text { Questionnaire on medical history } \\
\text { (standard hospital questionnaire) } \\
\text { Integrative medicine questionnaire (IMed questionnaire) } \\
\text { to collect data on complaints, current therapies, } \\
\text { co-medication and patient's goals } \\
\text { Physical examination } \\
\text { Lab results }\end{array}$ \\
\hline & $\downarrow$ \\
\hline \multirow[t]{2}{*}{$\begin{array}{l}\text { Integrative medicine } \\
\text { consultation }\end{array}$} & $\begin{array}{l}\text { After the initial appointment } \\
\text { Evaluation of the IMed questionnaire and of the } \\
\text { standard medical history questionnaire } \\
\text { Compilation of findings, medication(s) and goals } \\
\text { Drug therapy safety } \\
\text { Preparations for interdisciplinary integrative medicine } \\
\text { conference }\end{array}$ \\
\hline & $\downarrow$ \\
\hline \multirow[t]{2}{*}{$\begin{array}{l}\text { Interdisciplinary integrative } \\
\text { medicine conference }\end{array}$} & $\begin{array}{l}\text { Interdisciplinary integrative medicine conference } \\
\text { Gynecology (general gynecology or gynecologic specialties) } \\
\text { and/or gynecologic oncology } \\
\text { Naturopathic medicine } \\
\text { Internal medicine } \\
\text { Nutritional medicine } \\
\text { Physiotherapy } \\
\text { Psycho-oncology } \\
\text { Acupuncture } \\
\text { Individual therapy recommendations by the } \\
\text { interdisciplinary integrative medicine conference } \\
\text { Comprehensive, detailed, individual and holistic integrative } \\
\text { medicine treatment plan }\end{array}$ \\
\hline & $\downarrow$ \\
\hline \multirow[t]{2}{*}{$\begin{array}{l}\text { Integrative medicine } \\
\text { consultation }\end{array}$} & $\begin{array}{l}\text { Second appointment attended by the patient } \\
\text { Presentation of the interdisciplinary treatment } \\
\text { recommendations } \\
\text { Letter providing a summary of recommendations } \\
\text { handed to the patient } \\
\text { Additional documents (prescriptions, application } \\
\text { instructions, nutritional recommendations, etc.) } \\
\text { Integrative medicine diary (IMed diary) handed to patient }\end{array}$ \\
\hline & $\downarrow$ \\
\hline $\begin{array}{l}\text { Integrative medicine } \\
\text { consultation }\end{array}$ & $\begin{array}{l}\text { Follow-up appointment (after 3-6 months) } \\
\text { Discussion of IMed diary and review of compliance } \\
\text { Re-evaluation of the situation and modification } \\
\text { of CAM-specific therapy if required }\end{array}$ \\
\hline
\end{tabular}

\begin{tabular}{|c|}
\hline Flyer/business card \\
\hline $\begin{array}{c}\text { Standard questionnaire } \\
\text { on medical history }\end{array}$ \\
\hline $\begin{array}{c}\text { (Validated) } \\
\text { IMed questionnaire }\end{array}$ \\
\hline $\begin{array}{c}\text { Databases/ } \\
\text { drug therapy safety }\end{array}$ \\
\hline
\end{tabular}

Fig. 1 Standard operating procedure (SOP) for integrative medicine consultations.

\section{Integrative medicine patient questionnaire and diary}

An IMed questionnaire consisting of 43 questions was developed as the basis for the standard operating procedure for integrative medicine consultations (see appendix 1). This questionnaire and the patient's general medical and oncological history provide information which serves as the basis for the specific individual therapy recommendations offered in addition to standard cancer therapies.

The IMed questionnaire includes questions covering the following areas:

1. General information (including personal data, demographic data, disease, previous and current treatments, co-medication, social environment),
2. Lifestyle (including sports, diet),

3. Complementary and alternative therapies,

4. Physical and mental state (including complaints, quality of life), and

5. Patient's goals (including wishes, expectations).

An integrative medicine diary (IMed diary) was developed to assess the course of integrative therapy methods and patient compliance. (The IMed diary has not been included as it is too extensive. The main points are described below.) Patients were requested to enter general information (including personal information, course of disease, co-medication), their physical and psychological condition, lifestyle (including sports, diet), the use of integrative therapy methods and health-economic aspects in the 
Table 1 Overview of questions in the IMed diary.

\begin{tabular}{|c|c|c|c|c|c|c|}
\hline Month & $\begin{array}{l}\text { Medical history (gen. } \\
\text { information, disease, } \\
\text { treatment, medication) }\end{array}$ & $\begin{array}{l}\text { Complaints, physical } \\
\text { and psychological } \\
\text { condition }\end{array}$ & $\begin{array}{l}\text { Integrative } \\
\text { medicine/ } \\
\text { lifestyle }\end{array}$ & $\begin{array}{l}\text { Health eco- } \\
\text { nomics, treat- } \\
\text { ment costs }\end{array}$ & $\begin{array}{l}\text { Standard questionnaires } \\
\text { (FACT-G, IPAQ, HADS, NCCN's } \\
\text { Distress Thermometer) }\end{array}$ & $\begin{array}{l}\text { Expecta- } \\
\text { tions| } \\
\text { wishes }\end{array}$ \\
\hline 0 & $X$ & $X$ & $X$ & $X$ & $X$ & $X$ \\
\hline 3 & & $x$ & $x$ & $x$ & & \\
\hline 6 & & $x$ & $x$ & $X$ & $X$ & \\
\hline 9 & & $X$ & $X$ & $X$ & & \\
\hline 12 & & $x$ & $x$ & $X$ & $x$ & $X$ \\
\hline
\end{tabular}

Table 2 Results of the first validation of the IMed questionnaire (N/A = Not available, i.e. this answer option was not available) (total $\mathrm{n}=34)$.

\begin{tabular}{|c|c|c|c|c|c|}
\hline Questions & $\begin{array}{l}\text { Total } \\
\text { n (\%) }\end{array}$ & $\begin{array}{l}\text { Yes } \\
\text { n (\%) }\end{array}$ & $\begin{array}{l}\text { No } \\
\text { n (\%) }\end{array}$ & $\begin{array}{l}\text { To some extent } \\
\text { n (\%) }\end{array}$ & $\begin{array}{l}\text { Don't know } \\
\text { n (\%) }\end{array}$ \\
\hline Were the questions comprehensible? & $33(100)$ & $22(67)$ & $0(0)$ & $11(33)$ & $0(0)$ \\
\hline Were the questions too complicated? & $32(100)$ & $0(0)$ & $23(72)$ & $9(28)$ & $0(0)$ \\
\hline Was the questionnaire too long? & $31(100)$ & $10(32)$ & $20(65)$ & $\mathrm{N} / \mathrm{A}$ & $1(3)$ \\
\hline Did you like the questionnaire? & $27(100)$ & $16(59)$ & $1(4)$ & $10(37)$ & $0(0)$ \\
\hline Do you have suggestions for improvement? & $28(100)$ & $5(18)$ & $23(82)$ & N/A & $0(0)$ \\
\hline
\end{tabular}

IMed diary at the start of integrative therapy (month 0 ) and at the time points 3 (month 3), 6 (month 6), 9 (month 9) and 12 (month 12) ( Table 1). Parts of the diary of the PreFace study (Evaluation of Predictive Factors regarding the Effectivity of Aromatase Inhibitor Therapy) were used as the basis when we developed our patient diary [43]. The PreFace study is a phase IV study where postmenopausal, hormone receptor-positive breast cancer patients are treated with the aromatase inhibitor letrozole [44].

Moreover the EQ-5D health questionnaire (EuroQol - 5Dimensions), the IPAQ questionnaire measuring physical activity (International Physical Activity Questionnaire), the FACT-G questionnaire (Functional Assessment of Cancer Therapy - General), the HADS questionnaire (Hospital Anxiety and Depression Scale) and the National Comprehensive Cancer Network's (NCCN) Distress Thermometer already included standardized and previously validated elements [45-49]. Permissions to use licensed questionnaires and instruments in consultations and in our prospective study were sought and obtained. The questions were repeated at every follow-up at defined time points.

Prior to their first use by patients, the IMed questionnaire and the IMed diary were evaluated in terms of their contents and structure by three different independent medical experts and were revised in accordance with their recommendations.

\section{Data analysis and statistics}

Data were analyzed using IBM SPSS version 21 (IBM, Armonk, NY, USA). Statistical evaluation consisted of descriptive analysis. Total amounts, mean values and percentages were calculated. Data from different patient subgroups were collected and compared. Missing data were not included in the evaluation.

\section{Results \\ $\nabla$}

Validation in terms of comprehensibility and potential application was done in three different patient populations.

\section{First validation of the IMed questionnaire}

For the first validation, the IMed patient questionnaire was tested between December 2013 and February 2014 in a randomly se- lected patient population consisting of 34 oncological patients attending the Department of Gynecology and Obstetrics of Erlangen University Hospital, and evaluated using a specially developed assessment sheet $(n=34)$. The patients participating in the validation study were 26 breast cancer patients and 8 genital cancer patients. The specially developed assessment sheet consisted of 5 questions on the items "time required to complete the questionnaire", “comprehensibility", “complexity”, "length", "whether the patient liked the questionnaire" and "suggestions for improvement" (see IMed diary [ $\bullet$ Table 1$]$ ).

The majority of questioned patients stated that the questions were comprehensible (67\%) and appropriate in terms of complexity (72\%). $25 \%$ of patients considered the IMed questionnaire to be too long, and $5 \%$ of patients had suggestions for improvement ( Table 2). Average time taken to complete the IMed questionnaire was 28 minutes. $88 \%$ of patients required $\leq 30$ minutes to complete the questionnaire ( Table 3). A subgroup analysis of the patient population showed no differences between groups. Using the results of the first validation, the IMed questionnaire was modified with a view to improving comprehension and functionality. Modifications included shortening the length of the questionnaire, including the trade names of cancer drugs in addition to their active ingredients, reducing the number of "further comments" boxes, and improving the comprehensibility of questions assessed as too complex.

\section{Second validation of the revised IMed questionnaire and first validation of the IMed diary}

In the period from April to June 2014, 25 oncology patients attending the Department of Gynecology and Obstetrics of Erlangen University Clinic agreed to complete the revised IMed questionnaire and the first chapter of the IMed diary (month 0 [○ Table 1]) and to hand in an assessment sheet as was done for the first validation of the IMed questionnaire $(n=25)$. This time, the patient population consisted of 17 breast cancer patients and 8 patients with genital cancer. A second validation of the IMed questionnaire was done.

After revision of any complex and difficult to understand questions, $95 \%$ of patients considered the IMed questionnaire to be suitable in terms of its comprehensibility (96\%), complexity 
Table 3 Time required to complete the IMed questionnaire $(n=34 ; n=25)$ or the IMed diary $(n=25)$.

\begin{tabular}{|llll|}
\hline Time required for completion & $\begin{array}{l}\text { 1st validation } \\
\text { (IMed questionnaire) }\end{array}$ & $\begin{array}{l}\text { 2nd validation } \\
\text { (revised IMed questionnaire) }\end{array}$ & $\begin{array}{l}\text { 2nd validation } \\
\text { (IMed diary) }\end{array}$ \\
\hline Total $n(\%)$ & $34(100)$ & $25(100)$ & $25(100)$ \\
\hline$\leq 30$ min, $n(\%)$ & $30(88)$ & $17(68)$ & $18(72)$ \\
\hline$>30$ min, $n(\%)$ & $4(12)$ & $8(32)$ & $7(28)$ \\
\hline Minimum (min) & 10 & 10 & 8 \\
\hline Maximum (min) & 60 & 60 & 80 \\
\hline Mean (min) & 28 & 29 & 30 \\
\hline
\end{tabular}

Table 4 Results of the 2 nd validation of the revised IMed questionnaire (total $n=25)$ and 1st validation of the IMed diary (total $n=25)(N / A=n o t$ available, i.e. this answer option was not available).

\begin{tabular}{|c|c|c|c|c|c|}
\hline Questions & $\begin{array}{l}\text { Total } \\
\text { n (\%) }\end{array}$ & $\begin{array}{l}\text { Yes } \\
\text { n (\%) }\end{array}$ & $\begin{array}{l}\text { No } \\
\text { n (\%) }\end{array}$ & $\begin{array}{l}\text { To some extent } \\
\text { n (\%) }\end{array}$ & $\begin{array}{l}\text { Don't know } \\
\text { n (\%) }\end{array}$ \\
\hline \multicolumn{6}{|l|}{ IMed questionnaire } \\
\hline Were the questions comprehensible? & $25(100)$ & $24(96)$ & $0(0)$ & $1(4)$ & $0(0)$ \\
\hline Were the questions too complicated? & $25(100)$ & $0(0)$ & $24(96)$ & $1(4)$ & $0(0)$ \\
\hline Was the questionnaire too long? & $25(100)$ & $2(8)$ & $23(92)$ & $N / A$ & $0(0)$ \\
\hline Did you like the questionnaire? & $25(100)$ & $17(72)$ & $0(0)$ & $4(16)$ & $3(12)$ \\
\hline Do you have suggestions for improvement? & $25(100)$ & $1(4)$ & $14(56)$ & $N / A$ & $10(40)$ \\
\hline \multicolumn{6}{|l|}{ IMed diary } \\
\hline Were the questions comprehensible? & $25(100)$ & $24(96)$ & $0(0)$ & $1(4)$ & $0(0)$ \\
\hline Were the questions too complicated? & $25(100)$ & $0(0)$ & $23(92)$ & $2(8)$ & $0(0)$ \\
\hline Was the questionnaire too long? & $25(100)$ & $2(8)$ & $23(92)$ & N/A & $0(0)$ \\
\hline Did you like the questionnaire? & $25(100)$ & $18(72)$ & $0(0)$ & $4(16)$ & $3(12)$ \\
\hline Do you have suggestions for improvement? & $25(100)$ & $1(4)$ & $14(56)$ & $N / A$ & $10(40)$ \\
\hline
\end{tabular}

(96\%) and length (92\%) ( Table 4). The question on individual integrative medicine methods (question 39 of the IMed questionnaire) was excluded from the analysis as there had been problems of comprehension due to the fact that many of the therapies were not known to patients. This had been highlighted in the comments given by the patients on the assessment sheet. Only $4 \%$ of patients offered suggestions for improvement.

On average, $93 \%$ of patients were satisfied with the IMed diary, with $96 \%$ attesting that it was easy to understand, $92 \%$ stating that it was not too complex, $92 \%$ stating that it was not too long, and $4 \%$ making suggestions for improvement ( 0 Table 4 ). The average time taken to complete the revised IMed questionnaire was 29 minutes, and 30 minutes were taken to complete the IMed diary ( Table 3).

Patients older than 65 years of age required more time than younger patients.

Differences in patient age, disease status and type of treatment did not result in any differences with regard to assessment of comprehensibility, complexity and length of the IMed questionnaire.

Comparisons of individual subgroups of the patient population showed no significant differences, allowing both groups to be assessed together.

\section{Validation of the integrative medicine consultation}

In June 2014 a standardized integrative medicine consultation was launched at the Department of Gynecology and Obstetrics of Erlangen University Hospital. Since then, the consultation model has been investigated in a prospective cohort study consisting of 25 patients with the aim of validating the consultation procedure and evaluating the use of the IMed questionnaire $(n=25)$. In the period from June 6 to September 9, 2014, patients made an appointment on their own initiative to attend an inte- grative medicine consultation and receive individualized advice on CAM treatment. 18 of these patients had breast cancer and 5 patients had genital cancer. Patient satisfaction was evaluated in a telephone interview 4-6 weeks after the second appointment using a specially developed satisfaction assessment sheet. Patients were asked to evaluate the integrative medicine consultation, the interdisciplinary integrative medicine conference, the overall concept of the integrative medicine consultation, the therapy recommendations and the information material used (brochures, IMed questionnaire, letter, information, etc.).

Analysis showed that the integrative medicine consultation received excellent ratings with regard to patient satisfaction ( Table 5). $97 \%$ of patients assessed the consultation procedure, the overall concept, the questionnaire, the treatment plan developed for them, the letter, the information material and the overall care offered in the integrative medicine consultation as very positive ( $\bullet$ Table $\mathbf{5}$ ). $92 \%$ of patients considered the fact that an interdisciplinary integrative medicine conference was held after the first consultation, requiring them to attend two appointments, as a good thing. $96 \%$ of patients stated that they would recommend the integrative medicine consultation to other affected patients. The patients particularly welcomed the fact that they were given ample time and that the focus was on them as people and not on the cancer.

\section{Completeness and plausibility of data}

Completeness of data in the assessment sheets for the IMed questionnaire and the IMed diary and in the patient satisfaction sheets assessing the integrative medicine consultation was calculated as between $91-100 \%$ for the individual validations. A review of completed IMed questionnaires and IMed diaries showed that data completeness was $85-100 \%$. A plausibility check was carried out by one of the doctors to verify the quality of the data. The data were more than $95 \%$ plausible. 
Table 5 Analysis of patient satisfaction with the integrative medicine consultation $(n=25)$.

\begin{tabular}{|c|c|c|c|c|c|c|c|}
\hline Assessment & $\begin{array}{l}\text { Overall } \\
\mathrm{n}(\%)\end{array}$ & $\begin{array}{l}\text { Outstanding } \\
\text { n (\%) }\end{array}$ & $\begin{array}{l}\text { Very good } \\
\mathrm{n}(\%)\end{array}$ & $\begin{array}{l}\text { Good } \\
\text { n (\%) }\end{array}$ & $\begin{array}{l}\text { Indifferent } \\
\text { n (\%) }\end{array}$ & $\begin{array}{l}\text { Poor } \\
\text { n (\%) }\end{array}$ & $\begin{array}{l}\text { Very poor } \\
\text { n (\%) }\end{array}$ \\
\hline Procedure of the integrative medicine consultation & $25(100)$ & $11(44)$ & $11(44)$ & $2(8)$ & $0(0)$ & $1(4)$ & $0(0)$ \\
\hline IMed questionnaire & $25(100)$ & $7(28)$ & $7(28)$ & $10(40)$ & $1(4)$ & $0(0)$ & $0(0)$ \\
\hline Interdisciplinary integrative medicine conference & $25(100)$ & $18(72)$ & $4(16)$ & $3(12)$ & $0(0)$ & $0(0)$ & $0(0)$ \\
\hline Overall concept & $25(100)$ & $11(44)$ & $9(36)$ & $4(16)$ & $0(0)$ & $1(4)$ & $0(0)$ \\
\hline 2 appointments & $25(100)$ & $10(40)$ & $7(28)$ & $6(24)$ & $1(4)$ & $1(4)$ & $0(0)$ \\
\hline Development of the treatment plan & $25(100)$ & $14(56)$ & $10(40)$ & $0(0)$ & $0(0)$ & $0(0)$ & $1(4)$ \\
\hline $\begin{array}{l}\text { Letter, information material, } \\
\text { information on applications }\end{array}$ & $25(100)$ & $10(40)$ & $10(40)$ & $4(16)$ & $0(0)$ & $1(4)$ & $0(0)$ \\
\hline Overall treatment and care & $25(100)$ & $13(52)$ & $11(44)$ & $0(0)$ & $0(0)$ & $0(0)$ & $1(4)$ \\
\hline
\end{tabular}

\section{Discussion \\ $\nabla$}

The same standards should be set for the use of integrative medicine as for oncological therapies in evidence-based medicine. However, it is difficult to achieve this goal, as increases of knowledge in complementary medicine are usually based on experience, expertise and other forms of knowledge acquisition in contrast to scientific evidence-based medicine, and the two methods are based on different basic concepts [3]. Evidence-based medicine provides evidence for the efficacy and safety of an approach, which is often lacking for complementary medicine approaches. Good prospective randomized studies on integrative therapeutic methods are rare [50].

There are no standards, norms or methods in integrative medicine generally accepted as 'correct' (e.g. guidelines, medical treatment recommendations, directives). Achieving the same level for individual recommendations on integrative medicine given to a patient as those available for evidence-based standard therapies in senology or gynecologic oncology is therefore problematic [3]. The aim of this study was to offer patients a greater degree of safety and better quality of care in integrative medicine through standardization, the structuring of procedures, and the introduction of criteria which can be used as part of quality assurance in oncology [51] and to ascribe more value and confer a greater acceptance of integrative medicine.

There are numerous institutions for complementary and alternative therapies all over the world: centers for integrative medicine, clinics for complementary medicine or naturopathic treatment, institutes for holistic therapy, CAM consultations, naturopathy practices, etc. However, there is no standard in the literature outlining the procedure for integrative medicine consultations or the instruments required for such consultations. There are many questionnaires out there, but they are mostly survey questionnaires which aim to assess the incidence, reasons for, methods and general use of CAM by patients or to evaluate existing structures and the acceptance and attitude towards CAM of physicians and medical practitioners $[21,52]$. Prior to our study there was no published questionnaire which could be used as a standard instrument to record the current status in integrative medicine consultations and serve as a decision-making tool for CAM therapies. A PubMed search for CAM-specific patient diaries also returned no search results.

Patient assessment of our questionnaire on integrative medicine (IMed questionnaire) and the integrative medicine diary (IMed diary) with regard to the time required for completion and the comprehensibility, complexity and functionality of the questionnaire and the diary was positive. The standardized overall concept of the integrative medicine consultation and the instru- ments required for the consultation were considered suitable by the patients.

To further assess the standardized IMed questionnaire, the standardized IMed diary and the SOP for integrative medicine consultations, a prospective, non-interventional, observational study on integrative medicine is planned which aims to investigate the impact of integrative medicine on patient quality of life and on reducing side-effects in female cancer patients.

Our team is one of the first study groups to develop, validate and publish a standard for an IMed questionnaire, an IMed diary and an integrative medicine consultation. In future, the procedure used in integrative medicine consultations in the Department of Gynecology and Obstetrics at Erlangen University Hospital could be introduced in other hospitals and certified breast cancer and gynecologic cancer centers as a "standard operating procedure" (SOP). This would offer patients maximum safety and a standardized quality of care in integrative medicine.

\section{Acknowledgement}

Our thanks go to everyone involved in the development of the integrative medicine consultation.

\section{Conflict of Interest}

$\nabla$

The authors declare that there are no conflicts of interest with regard to any of the topics presented in this article.

\section{References}

1 Horneber M, Bueschel G, Dennert G et al. How many cancer patients use complementary and alternative medicine: a systematic review and metaanalysis. Integr Cancer Ther 2012; 11: 187-203

2 Molassiotis A, Scott JA, Kearney $N$ et al. Complementary and alternative medicine use in breast cancer patients in Europe. Support Care Cancer 2006; 14: 260-267

3 Hack CC, Hüttner NBM, Paepke D et al. Integrative Medizin in der Gynäkologischen Onkologie - Möglichkeiten und Grenzen Teil 1. Geburtsh Frauenheilk 2013; 73: R63-R80

4 Ernst E, Cassileth BR. The prevalence of complementary/alternative medicine in cancer: a systematic review. Cancer 1998; 83: 777-782

5 Chatwin J, Tovey P. Complementary and alternative medicine (CAM), cancer and group-based action: a critical review of the literature. Eur J Cancer Care (Engl) 2004; 13: 210-218

6 Paul M, Davey B, Senf B et al. Patients with advanced cancer and their usage of complementary and alternative medicine. J Cancer Res Clin Oncol 2013; 139: 1515-1522

7 Horneber M, Overkamp F, Rostock M. [Integration of integrative concepts - a survey]. Onkologie 2012; 35 (Suppl. 5): 3-11 
8 Molassiotis A, Fernadez-Ortega P, Pud D et al. Use of complementary and alternative medicine in cancer patients: a European survey. Ann Oncol 2005; 16: 655-663

9 Eschiti VS. Lesson from comparison of CAM use by women with femalespecific cancers to others: it's time to focus on interaction risks with CAM therapies. Integr Cancer Ther 2007; 6: 313-344

10 Richardson MA, Sanders T, Palmer JL et al. Complementary/alternative medicine use in a comprehensive cancer center and the implications for oncology. J Clin Oncol 2000; 18: 2505-2514

11 Deutsche Gesellschaft für Senologie. Interdisziplinäre S3-Leitlinie für die Diagnostik, Therapie und Nachsorge des Mammakarzinoms. Germering: W. Zuckschwerdt Verlag GmbH; 2012

12 Munstedt K, Kirsch K, Milch W et al. Unconventional cancer therapysurvey of patients with gynaecological malignancy. Arch Gynecol Obstet 1996; 258: 81-88

13 DiGianni LM, Garber JE, Winer EP. Complementary and alternative medicine use among women with breast cancer. J Clin Oncol 2002; 20: $34 \mathrm{~s}-38 \mathrm{~s}$

14 Jacobson JS, Verret WJ. Complementary and alternative therapy for breast cancer: the evidence so far. Cancer Pract 2001; 9: 307-310

15 Hlubocky FJ, Ratain MJ, Wen $M$ et al. Complementary and alternative medicine among advanced cancer patients enrolled on phase I trials: a study of prognosis, quality of life, and preferences for decision making. J Clin Oncol 2007; 25: 548-554

16 Schonekaes K, Micke O, Mucke R et al. [Use of complementary/alternative therapy methods by patients with breast cancer]. Forsch Komplementarmed Klass Naturheilkd 2003; 10: 304-308

17 Micke 0, Bruns F, Glatzel M et al. Predictive factors for the use of complementary and alternative medicine (CAM) in radiation oncology. Eur J Integr Med 2009; 1: 19-25

18 Blaes AH, Kreitzer MJ, Torkelson C et al. Nonpharmacologic complementary therapies in symptom management for breast cancer survivors. Semin Oncol 2011; 38: 394-402

19 Casla S, Hojman P, Márquez-Rodas I et al. Running away from side effects: physical exercise as a complementary intervention for breast cancer patients. Clin Transl Oncol 2015; 17: 180-196

20 Finnegan-John J, Molassiotis A, Richardson A et al. A systematic review of complementary and alternative medicine interventions for the management of cancer-related fatigue. Integr Cancer Ther 2013; 12 : 276-290

21 Fasching PA, Thiel F, Nicolaisen-Murmann Ket al. Association of complementary methods with quality of life and life satisfaction in patients with gynecologic and breast malignancies. Support Care Cancer 2007; 15: $1277-1284$

22 Molassiotis A, Browall M, Milovics L et al. Complementary and alternative medicine use in patients with gynecological cancers in Europe. Int J Gynecol Cancer 2006; 16 (Suppl. 1): 219-224

23 Shneerson C, Taskila T, Gale $N$ et al. The effect of complementary and alternative medicine on the quality of life of cancer survivors: a systematic review and meta-analyses. Complement Ther Med 2013; 21: 417-429

24 Gerber B, Scholz C, Reimer T et al. Complementary and alternative therapeutic approaches in patients with early breast cancer: a systematic review. Breast Cancer Res Treat 2006; 95: 199-209

25 Paul M, Davey B, Senf B et al. Patients with advanced cancer and their usage of complementary and alternative medicine. J Cancer Res Clin Oncol 2013; 139: 1515-1522

26 Tautz E, Momm F, Hasenburg A et al. Use of complementary and alternative medicine in breast cancer patients and their experiences: a cross-sectional study. Eur J Cancer 2012; 48: 3133-3139

27 Hack CC, Voiß P, Lange S et al. Mammakarzinom: Symptome lindern mit Methoden der Integrativen Medizin. Geburtsh Frauenheilk 2015; in press

28 Institut zur Evaluation naturheilkundlicher Verfahren. Online: http:// www.iwenv.de/; last access: 2015

29 National Center of Complementary and Alternative Medicine (NCCAM). Complementary, alternative and integrative Health. Online: http:// nccam.nih.gov/health/whatiscam; last access: 2013

30 Consortion of Academic Health Centers for Integrative Medicine (CAHCIM). About us. Online: http://www.imconsortium.org/about/; last access: 2013

31 Sundberg T, Halpin J, Warenmark A et al. Towards a model for integrative medicine in Swedish primary care. BMC Health Serv Res 2007; 7: 107
32 Dobos G, Wilhelm $M$. [Model projects in integrated oncology]. Onkologie 2012; 35 (Suppl. 5): 21-25

33 Buchanan DR, White JD, O'Mara AM et al. Research-design issues in cancer-symptom-management trials using complementary and alternative medicine: lessons from the National Cancer Institute Community Clinical Oncology Program experience. J Clin Oncol 2005; 23: 66826689

34 El Saghir NS, Keating NL, Carlson RWet al. Tumor boards: optimizing the structure and improving efficiency of multidisciplinary management of patients with cancer worldwide. Am Soc Clin Oncol Educ Book 2014; DOI: 10.14694/EdBook_AM.2014.34.e461

35 Keating NL, Landrum MB, Lamont EB et al. Tumor boards and the quality of cancer care. J Natl Cancer Inst 2013; 105: 113-121

36 Wilson AR, Marotti L, Bianchi $S$ et al. The requirements of a specialist Breast Centre. Eur J Cancer 2013; 49: 3579-3587

37 Deutsche Krebsgesellschaft (DKG). Jahresbericht 2015 der zertifizierten Onkologischen Zentren. Online: http://www.krebsgesellschaft.de/ deutsche-krebsgesellschaft-wtrl/deutsche-krebsgesellschaft/ zertifizierung/jahresberichte.html; last access: 2015

38 Deutsche Krebsgesellschaft (DKG). Kennzahlenauswertung 2014, Jahresbericht der zertifizierten Brustzentren. Online: http://www.krebsgesellschaft.de/deutsche-krebsgesellschaft-wtrl/deutsche-krebsgesellschaft/zertifizierung/jahresberichte.html; last access: 2015

39 Beckmann MW, Adler G, Albers P et al. Dreistufenmodell optimiert Behandlung unter Kostendeckung. Dtsch Arztebl 2007; 104: A3004A3009

40 Beckmann MW, Jud SM. Gynäkologische Krebszentren - Kompetenzbündelung zur Qualitätsverbesserung. Frauenheilk up2date 2009; 3: 71-74

41 Wesselmann S, Beckmann MW, Winter A. The concept of the certification system of the German Cancer Society and its impact on gynecological cancer care. Arch Gynecol Obstet 2014; 289: 7-12

42 Beckmann MW, Quaas J, Bischofberger A et al. Establishment of the Certification System "Gynaecological Dysplasia" in Germany. Geburtsh Frauenheilk 2014; 74: 860-867

43 Beckmann MW, Hein A, Bayer CM et al. Einsatz von integrativen Heilmethoden durch postmenopausale Mammakarzinompatientinnen in der PreFace Phase IV Studie - eine prospektive, longitudinale Untersuchung. Deutscher Senologiekongress 2013; Poster P034

44 Fasching PA, Fehm T, Kellner S et al. Evaluation of therapy management and patient compliance in postmenopausal patients with hormone receptor-positive breast cancer receiving letrozole treatment: the EvaluateTM study. Geburtsh Frauenheilk 2014; 74: 1137-1143

45 EuroQol Group. EuroQol - a new facility for the measurement of health-related quality of life. Health Policy 1990; 16: 199-208

46 Craig $C L$, Marshall AL, Sjostrom $M$ et al. International physical activity questionnaire: 12-country reliability and validity. Med Sci Sports Exerc 2003; 35: 1381-1395

47 Cella DF, Tulsky DS, Gray G et al. The functional assessment of cancer therapy scale: development and validation of the general measure. J Clin Oncol 1993; 11: 570-579

48 Zigmond AS, Snaith RP. The hospital anxiety and depression scale. Acta Psychiatr Scand 1983; 67: 361-370

49 Roth AJ, Kornblith AB, Batel-Copel L et al. Rapid screening for psychologic distress in men with prostate carcinoma: a pilot study. Cancer 1998; 82: 1904-1908

50 Witt CM, Ausserer O, Baier S et al. Effectiveness of an additional individualized multi-component complementary medicine treatment on health-related quality of life in breast cancer patients: a pragmatic randomized trial. Breast Cancer Res Treat 2015; DOI: 10.1007/s10549014-3249-3

51 Leitlinienprogramm Onkologie der AWMF, Deutschen Krebsgesellschaft e.V. und Deutschen Krebshilfe e.V. Leitlinienprogramm Onkologie S3Leitlinie Brustkrebs. Germering: W. Zuckschwerdt Verlag GmbH; 2012

52 Huebner J, Prott FJ, Micke $O$ et al. Online survey of cancer patients on complementary and alternative medicine. Oncol Res Treat 2014; 37: 304-308

The IMed questionnaire is available online in German at: https://www.thieme-connect.de/media/gebfra/201504/supmat/ 10-1055-s-0035-1545850-sup_gf909.pdf 